\title{
OPTIMALISASI TINGKAT PERTUMBUHAN (Growth Rate) DAN MORTALITAS (Survival Rate) IKAN NILA (Oreochromis niloticus) DENGAN ENZIM PAPAIN KASAR
}

\author{
Muhsinul Ihsan dan Alwan Mahsul \\ Dosen Jurusan Pendidikan IPA Biologi FITK IAIN Mataram
}

\begin{abstract}
Abstrak
Ikan Nila adalah salah satu ikon penyelamat perkembangan budi daya ikan air tawar karena teknologi pemeliharaannya sudah berkembang dengan baik. Salah satu permasalahan dalam pembudidayaan Ikan Nila adalah mahalnya biaya pakan. Solusi untuk mengatasi hal ini adalah pengayaan pakan yang memiliki kualitas rendah dengan enzim papain kasar. Tujuan penelitian ini adalah untuk mengetahui pengaruh enzim papain kasar terhadap pertumbuhan dan survival rate Ikan Nila. Penelitian ini telah dilakukan selama 30 hari di kolam budidaya milik masyarakat Gubuk Barat I Desa Mamben Daya Kec. Wanasaba Lombok Timur. Terdapat 4 tahapan dalam prosedur kerja yang digunakan yaitu: preparasi enzim papain kasar, pencampuran enzim papain kasar dengan pelet, pengujian pelet yang telah dicampur dengan enzim papain kasar, dan evaluasi pengaruh enzim papain kasar. Hasil penelitian menunjukkan bahwa enzim papain kasar mampu meningkatkan pertumbuhan Ikan Nila sebesar $4 \mathrm{Kg}$ selama 30 hari, hampir empat kali lipat lebih tinggi dibandingkan pertumbuhan Ikan Nila yang tidak diberikan enzim papain kasar. Survival rate Ikan Nila yang ditambahkan enzim papain kasar sebesar 78,09\%, lebih besar dibandingkan survival rate Ikan Nila yang tidak ditambahkan enzim papain kasar. Enzim papain kasar mampu meningkatkan pertumbuhan Ikan Nila secara signifikan. Akan tetapi, belum mampu menekan tingkat mortalitas Ikan Nila secara signifikan.
\end{abstract}

Kata Kunci: Ikan Nila, Papain, pertumbuhan, survival rate 


\section{PENDAHULUAN}

Ikan nila (Oreochromis niloticus) merupakan spesies yang berasal dari kawasanSungai Nil dan danau-danau sekitarnya di Afrika. Bentuk tubuh memanjang, pipi kesamping dan warna putih kehitaman. Jenis ini merupakan ikan konsumsi air tawar yang banyak dibudidayakan setelah Ikan Mas (Cyrprinus Carpio) dan telah dibudidayakan di lebih dari 85 negara termasuk Indonesia.

Pengembangan budidaya Ikan Nila di Indonesia tersebar secara luas. Dengan adanya luas perairan umum di Indonesia yang terdiri dari sungai dandanau buatan seluas hampir mendekati 13 juta ha merupakan potensi alam yang sangat baik bagi pengembangan usaha budidaya Ikan Nila di Indonesia.

Peluang pasar Ikan Nila cukup besar baik di pasar lokal maupun ekspor. Kebutuhan pasar dalam negeri untuk ikan nila umumnya berukuran dibawah 500gram/ekor, dengan harga berkisar antara Rp. 11.000-15.000/kg untuk wilayah Jawa dan Sumatera, sedangkan untuk wilayah timur Indonesia mencapai Rp. 20.000-35.000/kg. Kebutuhan pasar ekspor umumnya dalam bentuk fillet dengan harga berkisar Rp. 40.000-50.000/kg dengan Negara tujuan ekspor yaitu Amerika Serikat, Eropa, Timur Tengah, dan Hongkong. Untuk mendapatkan $1 \mathrm{~kg}$ fillet Nila, dibutuhkan 3 ekor ikan nilasegar. Oleh karena itu upaya pengembangan usaha budidaya Nila masih terbuka untuk dikembangkan dalam berbagai skala usaha.

Ikan ini diharapkan dapat menjadi salah satu ikon penyelamat perkembangan budi daya ikan air tawar karena teknologi pemeliharaannya sudah berkembang dengan baik. Namun, permasalahan yang adadi masyarakat saat ini yaitu kualitas benih dan induk yang kurang memadai. Akibatnya, produktifitas dan laju pertumbuhannya menurun. Selain itu, masalah serangan bakteri Streptococcus turut andil dalam menurunkan produktifitas ikan nila dibeberapa daerah. Optimalisasi laju pertumbuhan (growth rate) dan mortalitas (Survival Rate) Ikan Nila harus segera dilakukan untuk menyelamatkan aktivitas budidaya Ikan Nila. Hal ini sangat 
penting dilakukan karena aktivitas budidaya Ikan Nila akan mati jika laju pertumbuhan (growth rate) dan mortalitas (Survival Rate) Ikan Nila sangat rendah.

Enzim papain kasar yang diekstrak dari buah pepaya (Carica papaya) yang matang merupakan salah satu solusi alternatif untuk mengoptimalisasi laju pertumbuhan (growth rate) dan mortalitas (Survival Rate) Ikan Nila. Enzim papain kasar tidak murni mengandung enzim papain (protease). Akan tetapi, masih bercampur dengan senyawa yang lain seperti lipase, amilase, protein, dan lemak. Enzim protease berperan dalam menguraikan makromolekul protein menjadi senyawa penyusunnya yang lebih sederhana. Sedangkan lipase dan amilase berperan dalam menguraikan lipid dan karbohidrat. Penambahan enzim papain kasar pada substratnya dalam hal ini protein, lipid, dan karbohidrat dalam pelet ikan akan menyebabkan makromolekul-makromolekul tersebut akan terurai terlebih dahulu sebelum dimakan oleh ikan.

Tujuan penelitian ini adalah untuk mengetahui tingkat optimal pertumbuhan (growth rate) dan mortalitas (Survival Rate) Ikan Nila (Oreochromis nilotichus) dengan enzim papain kasar.

\section{METODE PENELITIAN}

\section{a. Bahan Penelitian}

Bahan untuk preparasi enzim papain kasar yang digunakan adalah pepaya yang sudah matang dengan berat 1 Kg didapatkan dari petani pepaya di Desa Mamben Daya, sedangkan bahan untuk uji coba enzim papain adalah Ikan Nila sebanyak 513 ekor dengan kisaran berat 57-90 gram/ekor.

\section{b. Rancangan Percobaan}

Rancangan percobaan yang digunakan pada penelitian ini adalah Rancangan Acak Lengkap (RAL) dengan 2 perlakuan dan 2 ulangan sehingga total unit percobaan sebanyak 4 unit percobaan. Perlakuan pertama adalah pelet tidak ditambahkan 
enzim papain kasar, sedangkan perlakuan kedua pelet ditambahkan enzim papain kasar

\section{c. Prosedur Kerja}

\section{Penyiapan Enzim Papain Kasar}

Enzim papain kasar diekstrak dari buah pepaya yang sudah matang. Ekstraksi enzim papain kasar dilakukan dengan cara menghancurkan sel-sel dalam buah pepaya menggunakan blender. Hasil ekstraksi kemudian dikeringkan dan dibuat menjadi serbuk

\section{Aplikasi Enzim Papain Kasar dalam Pelet Ikan}

Enzim papain kasar dilarutkan dalam air secukupnya kemudian disemprotkan secara merata ke seluruh pakan. Takaran yang digunakan adalah 50 cc enzim papain kasar / $1 \mathrm{Kg}$ pelet ikan. Pemberian pelet pada ikan dilakukan secara adlibitum (sampai kenyang)

\section{Teknik Pengumpulan Data}

Penelitian telah dilakukan selama 30 hari (Juli Agustus 2016). Data yang diambil selama penelitian adalah data tingkat pertumbuhan dan mortalitas. Data tingkat pertumbuhan diukur dengan cara menimbang biomassa ikan pada masing-masing unit percobaan. Penimbangan dilakukan di awal penelitian (hari ke-0) dan setelah penelitian selesai (hari ke-30). Data mortalitas diukur dengan cara menghitung jumlah ikan di awal penelitian (hari ke-0) dan hari terakhir penelitian (hari ke-30). Penghitungan dilakukan pada masing-masing unit percobaan.

\section{d. Teknik Analisis Data}

Data tingkat pertumbuhan dihitung dengan rumus:

(Total Biomassa awal-Total Biomassa akhir) 
Data Survival Rate dihitung dengan rumus:

[(Likan di awal penelitian-Likan di akhir penelitian)x100\%]

Untuk membuktikan tingkat signifikansi efek enzim papain kasar terhadap tingkat pertumbuhan dan mortalitas, data dianalisis dengan menggunakan software SPSS 15 dan Microsoft excel

\section{HASIL DAN PEMBAHASAN}

Hasil penelitian tentang Optimalisasi tingkat pertumbuhan dan Survival Rate Ikan Nila dengan Enzim Papain Kasar dapat dilihat dalam gambar 1 dan Gambar 2 .

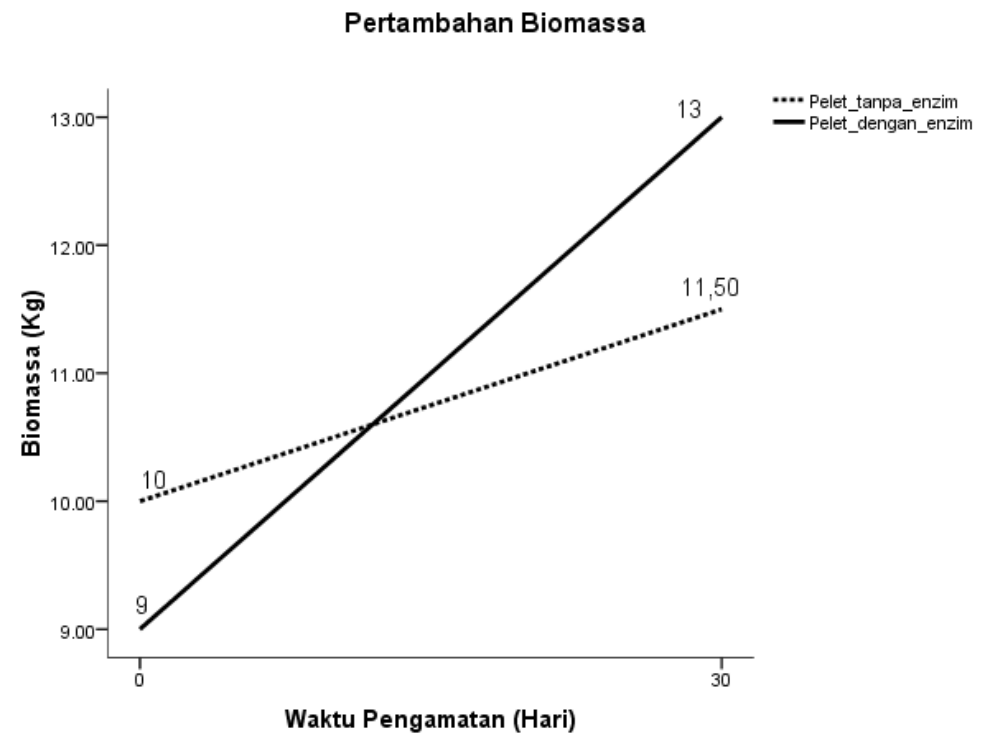

Gambar 1. Grafik Tingkat Pertumbuhan Ikan Nila

194 BIOTA: Jurnal Tadris IPA Biologi FITK IAIN Mataram 


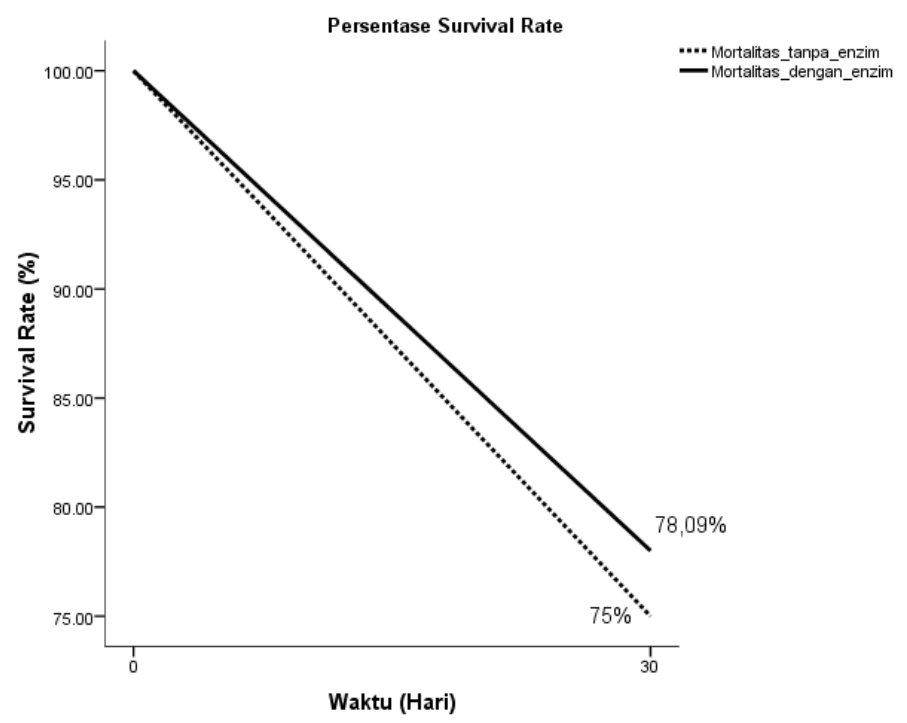

Gambar 2. Grafik Persentase Survival Rate

Berdasarkan Gambar 1 tentang grafik tingkat pertumbuhan Ikan Nila, penambahan enzim papain kasar pada pelet mampu meningkatkan pertumbuhan Ikan Nila. Pada pengamatan 0 hari, Ikan Nila memiliki biomassa rata-rata $9 \mathrm{Kg}$ kemudian setelah 30 hari biomassa Ikan Nila bertambah menjadi rata-rata $13 \mathrm{Kg}$. Apabila dikurangi biomassa akhir dan awal maka akan didapatkan bahwa Ikan Nila mengalami penambahan biomassa sebanyak $4 \mathrm{Kg}$ selama 30 hari.

Biomassa Ikan Nila yang tidak ditambahkan enzim papain kasar juga mengalami peningkatan. Akan tetapi, peningkatannya tidak setinggi Ikan Nila yang ditambahkan enzim papain kasar. Pada pengamatan hari ke-0 biomassa Ikan Nila rata-rata sebesar $10 \mathrm{Kg}$ kemudian pada hari ke-30 bertambah menjadi rata-rata 11,5 Kg. Pertambahan biomassa sebesar 1,5 Kg selama 30 hari. Berdasarkan hasil ini, dapat dikatakan bahwa Ikan Nila yang diberikan enzim papain memiliki tingkat pertumbuhan yang 
lebih tinggi dibandingkan Ikan Nila yang tidak diberikan enzim papain kasar.

Analisis of Varian (ANOVA) menujukkan bahwa perbedaan peningkatan biomassa yang muncul akibat penambahan enzim papain sangat signifikan. Hasil analisis uji ANOVA menunjukkan nilai signifikasi antar perlakuan (Between Group) sebesar 0,038 lebih kecil dibandingkan nilai signifikansi yang ditetapkan yaitu $\alpha=0,05(\mathrm{P}<0,05)$. Berdasarkan hal ini, perlakuan pelet yang ditambahkan enzim papain kasar memiliki dampak yang sangat signifikan untuk meningkatkan pertumbuhan Ikan Nila.

Berdasarkan gambar 2 tentang grafik Survival Rate (SR) Ikan Nila, penambahan enzim papain kasar pada pelet mampu menekan tingkat mortalitas (angka kematian) Ikan Nila. Pada pengamatan hari ke-0, Ikan Nila memiliki Survival Rate (SR) 100\% kemudian setelah 30 hari Survival Rate (SR) Ikan Nila menurun menjadi 78,09\%. Apabila dikurangi Survival Rate (SR) akhir dan awal maka akan didapatkan tingkat mortalitas Ikan Nila sebesar 21,91\%.

Survival Rate (SR) Ikan Nila yang tidak ditambahkan enzim papain kasar juga mengalami penurunan. Penurunannya lebih tinggi dibandingkan Ikan Nila yang ditambahkan enzim papain kasar. Pada pengamatan hari ke-0 Survival Rate Ikan Nila sebesar $100 \%$ kemudian pada hari ke-30 berkurang menjadi 75\%. Apabila dikurangi SR awal dan akhir akan didapatkan tingkat mortalitasnya sebesar $25 \%$ lebih tinggi $4 \%$ dibandingkan SR Ikan Nila yang ditambahkan enzim papain kasar. Berdasarkan hasil ini, dapat dikatakan bahwa Ikan Nila yang diberikan enzim papain memiliki tingkat mortalitas yang lebih rendah dibandingkan Ikan Nila yang tidak diberikan enzim papain kasar. 
Hasil uji normalitas menunjukkan tingkat signifikansi Shapiro-Wilk 0,894 lebih besar dibandingkan nilai $\alpha=0,05$ $(\mathrm{P}>0,05)$. Dengan demikian, data tingkat pertumbuhan sudah memenuhi syarat untuk dilakukan uji ANOVA.

Hasil analisis uji ANOVA menunjukkan nilai signifikasi antar perlakuan (Between Group) sebesar 0,854 lebih besar dibandingkan nilai signifikansi yang ditetapkan yaitu $\alpha=0,05$ $(\mathrm{P}>0,05)$. Berdasarkan hal ini, perlakuan pelet yang ditambahkan enzim papain kasar tidak memiliki dampak yang sangat signifikan untuk menekan mortalitas Ikan Nila.

Enzim papain kasar mampu menekan tingkat mortalitas Ikan Nila meskipun hasilnya tidak signifikan. Hal ini menandakan bahwa imunitas Ikan Nila mampu ditingkatkan oleh enzim papain kasar. Penyerapan nutrien yang lebih mudah, cepat dan efisien akan mengakibatkan sel-sel tubuh selalu mendapatkan nutrien yang cukup dalam rentang waktu yang singkat sehingga sintesis protein untuk pertumbuhan dapat berlangsung lebih cepat dan sistem - sistem tubuh yang lain termasuk sistem "fish self defence" berupa antibodi terbangun secara proporsional. Berdasarkan hasil uji prasyarat disimpulkan bahwa data tersebut terdistribusi normal dan homogen. Oleh karena itu, uji hipotesis dengan ANOVA 2 jalur dapat dilanjutkan. Hasil uji hipotesis menunjukkan pada taraf signifikan 5\% diperoleh nilai $F_{\text {hitung }}$ sebesar 0,0044. Harga $F_{\text {hitung }}$ tersebut lebih kecil dari $\mathrm{F}_{\text {tabel }}\left(\mathrm{F}_{\text {hitung }}<\mathrm{F}_{\text {tabel }}=0,0044<3.96\right)$ artinya Ha ditolak dan Ho diterima

\section{KESIMPULAN}

Berdasarkan hasil penelitian yang didapatkan, simpulan yang dapat diambil antara lain:

1.

Enzim papain kasar

meningkatkan pertumbuhan Ikan Nila secara signifikan. 
2.

Enzim papain kasar

belum mampu menurunkan tingkat mortalitas Ikan Nila secara signifikan

\section{DAFTAR PUSTAKA}

Anggraini, Aridita \& Yunianta, 2015, Pengaruh Suhu dan Lama Hidrolisis Enzim Papain Terhadap Sifat Kimia, Fisik dan Organoleptik Sari Edamame, Jurnal Pangan dan Agroindustri Vol. 3 No 3 p. 1015-1025

Dinas Kelautan dan Perikanan Sulawesi Tengah, 2013, Petunjuk Teknis Pembenihan dan Pembesaran Ikan Nila (Oreochromis niloticus), DKP Sulteng, Jakarta.

Effendie, M.I., 1997, Biologi Perikanan. Yayasan Pustaka Nusantara, Yogyakarta

Fairuz, M., 2013, Aplikasi Enzim Pada Ikan. Makalah Ilmiah. Disampaikan Pada Seminar Nasional Perikanan UGM, Yogyakarta.

Gamboa-Delgado. L., M. Molina-Poveda, C. Cahu. 2003. Digestive enzyme activity and food ingesta in juvenile shrimp Litopenaeus vannamei (Boone, 1931) as a function of body weight. Aquaculture Research, 34:1403-1411.

Glazer, 1971 dalam Wibisono, 2011, Imobilisasi Crude Enzim Papain Yang Diisolasi dari Getah Buah Pepaya, Makalah Ilmiah, didownload pada tanggal 6 September 2015 dari http://repository.usu.ac.id/bitstream/123456789/24170/ 4/Chapter\%20II.pdf

Grisham, Charles M.; Reginald H. Garrett (1999). Biochemistry. Philadelphia: Saunders College Pub. hlm. 426-7. ISBN 0-03022318-0. 
Harrison et al, 1997 dalam Wibisono, 2011, Imobilisasi Crude Enzim Papain Yang Diisolasi dari Getah Buah Pepaya, Makalah Ilmiah, didownload pada tanggal 6 September 2015 dari http://repository.usu.ac.id/bitstream/ 123456789/24170/4/Chapter\%20II.pdf

Kalk, 1975 dalam Wibisono, 2011, Imobilisasi Crude Enzim Papain Yang Diisolasi dari Getah Buah Pepaya, Makalah Ilmiah, didownload pada tanggal 6 September 2015 dari http://repository.usu.ac.id/bitstream/123456789/24170/ 4/Chapter\%20II.pdf

Kumlu, M., 1999. Feeding and Digestion in Larval Decapod Crustaceans. Tr. J. Of Biology. 23: 215-229. 